\title{
Defects in gut and enteric nervous system development in Talpid3 mutant chicken
}

\author{
JM Delalande*, AM Campbell, N Thapar, AJ Burns \\ From First International Cilia in Development and Disease Scientific Conference (2012) \\ London, UK. 16-18 May 2012
}

\section{Background}

The Talpid3 gene (KIAA0586) encodes a centrosomal protein essential for primary cilia formation and for normal Hedgehog $(\mathrm{Hh})$ signalling. Since the Hh signalling pathway has been implicated in the development of the gastrointestinal tract and enteric nervous system (ENS), our aim was to examine Talpid 3 mutant embryos to gain further insight into the role of the Hh pathway in the development of these tissues.

\section{Methods}

Fertilized eggs from the Talpid3 flock (The Roslin Institute), were incubated for up to 8 days. Embryos were fixed at different time points, and processed for immunohistochemistry to identify cell types, and in situ hybridization for components of the shh pathway.

\section{Results}

Macroscopically, the gut of Talpid3 mutants was normally patterned but overall gut length was significantly reduced. Although ENS precursors and neurons were distributed along the length of the gut, ENS cells were scattered rather than arranged in typical plexuses. Also, the organisation of smooth muscle actin (SMA) and the patterning of the shh pathway components were considerably altered in mutants.

\section{Conclusions}

We describe a number of phenotypic defects in Talpid 3 mutant gut. The reduced gut length suggests a lack of smooth muscle cell proliferation. The disorganized pattern of SMA and ENS suggests that cilia-mediated Hh signalling is essential for orchestrating the harmonious patterning of the different cell types necessary for normal gut development. We also demonstrate that the Talpid3 chicken is an excellent model to study related human gut

\footnotetext{
* Correspondence: j.delalande@ucl.ac.uk
}

UCL Institute of Child Health, UK

(C) 2012 Delalande et al; licensee BioMed Central Ltd. This is an Open Access article distributed under the terms of the Creative Commons Attribution License (http://creativecommons.org/licenses/by/2.0), which permits unrestricted use, distribution, and reproduction in any medium, provided the original work is properly cited. abnormalities, such as tracheoesophageal fistula and anorectal malformations, which are Hh-dependent.

Published: 16 November 2012

\section{doi:10.1186/2046-2530-1-S1-P85}

Cite this article as: Delalande et al:: Defects in gut and enteric nervous system development in Talpid3 mutant chicken. Cilia 2012 1(Suppl 1): P85.
Submit your next manuscript to BioMed Central and take full advantage of:

- Convenient online submission

- Thorough peer review

- No space constraints or color figure charges

- Immediate publication on acceptance

- Inclusion in PubMed, CAS, Scopus and Google Scholar

- Research which is freely available for redistribution
( Biomed Central 